\title{
$16 S$ ribosomal RNA sequencing and molecular serotyping of Avibacterium paragallinarum isolated from Indian field conditions
}

\author{
Vihang Vithalrao Patil ${ }^{1}$, Debendranath Mishra $^{2}$ and Dilip Vithalrao Mane ${ }^{3}$ \\ 1. Department of Biotechnology, Biotechnology Research Centre, College of Computer Sciences and IT, Latur - 413512 , \\ Maharashtra, India; 2. Swami Ramanand Teerth Marathwada University Sub-Centre, Latur - 413 531, Maharashtra, \\ India; 3. Indovax Private Limited, Gurgaon - 122 001, Haryana, India. \\ Corresponding author: Vihang Vithalrao Patil, e-mail: vihang.patil11@gmail.com \\ Co-authors: DM: drdeben108@gmail.com, DVM: manedv@rediffmail.com \\ Received: 08-04-2017, Accepted: 31-07-2017, Published online: 29-08-2017
}

doi: 10.14202/vetworld.2017.1004-1007 How to cite this article: Patil VV, Mishra D, Mane DV (2017) 16S ribosomal RNA sequencing and molecular serotyping of Avibacterium paragallinarum isolated from Indian field conditions, Veterinary World, 10(8): 1004-1007.

\begin{abstract}
Aim: This study was aimed at identifying Indian field isolates of Avibacterium paragallinarum on both molecular as well as serological levels that cause infectious coryza in chickens.

Materials and Methods: Species-specific polymerase chain reaction (HPG-2 PCR), and 16S ribosomal RNA (rRNA) sequencing were employed for molecular identification. Whereas, multiplex PCR technique was used for serological identification of Indian field isolates of A. paragallinarum.

Results: All three field isolates were identified as A. paragallinarum using HPG-2 PCR. The species-specific PCR results were validated using 16S rRNA sequencing. The partial 16S rRNA sequences obtained from all three isolates showed 96-99\% homology with the NCBI database reference strains of $A$. paragallinarum. The aligned partial sequences of $16 \mathrm{~S}$ rRNA were submitted to GenBank, and accession numbers were obtained. Multiplex PCR-based molecular serotyping showed that there are three serotypes of field isolates of A. paragallinarum, namely, strain IND101 is serovar A, strain IND102 is serovar B, and strain IND103 is serovar C.

Conclusion: HPG-2 PCR, 16S rRNA sequencing, and multiplex PCR are proved to be more accurate, sensitive, and reliable diagnostic tools for molecular and serological identification of $A$. paragallinarum field isolates. These diagnostic methods can substitute conventional cultural characterization and would be much valuable to formulate quick and correct prevention and control measures against this detrimental poultry pathogen.
\end{abstract}

Keywords: Avibacterium paragallinarum, HPG-2 PCR, infectious coryza, multiplex polymerase chain reaction, India, $16 \mathrm{~S}$ ribosomal RNA sequencing.

\section{Introduction}

Avian infectious coryza is an acute upper respiratory disease in chickens manifested by common symptoms such as nasal discharge, sneezing, facial edema, and conjunctivitis [1]. It is a cosmopolitan disease observed wherever extensive poultry operations exist. The disease increases cull formation in broilers and reduce egg production in layers substantially $(10-40 \%)$ [2]. It indicates bacterial disease control is an important issue in poultry farms $[3,4]$. Infectious coryza is caused by Gram-negative short rod bacterium Avibacterium paragallinarum. The bacterium is a slow-growing and fastidious organism needs NAD (factor V) for in vitro growth [5]. A. paragallinarum is classified into three serotypes, i.e., serovars A, B, and $\mathrm{C}[6]$.

\footnotetext{
Copyright: Patil, et al. Open Access. This article is distributed under the terms of the Creative Commons Attribution 4.0 International License (http://creativecommons.org/licenses/by/4.0/), which permits unrestricted use, distribution, and reproduction in any medium, provided you give appropriate credit to the original author(s) and the source, provide a link to the Creative Commons license, and indicate if changes were made. The Creative Commons Public Domain Dedication waiver (http://creativecommons.org/ publicdomain/zero/1.0/) applies to the data made available in this article, unless otherwise stated.
}

Commonly, A. paragallinarum gets masked and overgrown by other hemophilic organisms belongs to family Pasteurellaceae such as Avibacterium avium, Avibacterium gallinarum, and Avibacterium volantium [7]. Conventionally, the disease is diagnosed merely by symptoms and confirmed by isolating the organism in culture with satellite growth [8].

There is a possibility that regular diagnostic methods are not effective and can misinterpret infectious coryza with other poultry diseases. To overcome this situation, there is a need to use more sensitive and accurate method for diagnosis and confirmation of $A$. paragallinarum. At present, many alternative approaches such as species-specific polymerase chain reaction (HPG-2 PCR) [9], DNA Restriction endonuclease analysis [10], ribotyping [11], ERIC-PCR [12], real-time PCR [13], and $16 \mathrm{~S}$ ribosomal RNA (rRNA) sequencing $[7,14]$ are employed and found to be more precise and sensitive identifying tools for $A$. paragallinarum. The serovar level recognition of $A$. paragallinarum is widely carried out using HA-HI test [6]. Recently, the multiplex PCR-based molecular serotyping is also getting popular for molecular serotyping of causative agent [15]. 
In India, infectious coryza was first reported in the 1950s. Since then, it is one of the commonly found diseases in many poultry pockets of the country [16-19]. Unfortunately, the information about outbreaks and disease prevalence is very scanty due to tedious isolation procedure and fastidious nature of this organism [20]. However, modern diagnostic approaches are observed to be more successful in the authentic identification and characterization of A. paragallinarum at the molecular level to control disease. To control bacterial diseases, different strategies can be implemented in poultry farms [21-23].

The present study was conducted on species-specific PCR and 16S rRNA sequencing for identification of $A$. paragallinarum field isolates. Multiplex PCR-based molecular serotyping was also performed for very first time in India to sort A. paragallinarum field isolates on serological level. The identified three isolates used in this study were previously isolated and studied for their virulence pattern by the present authors from different geographical locations of India between the years 2012 and 2015 [24,25].

\section{Materials and Methods}

\section{Ethical approval}

No ethical approval was necessary to conduct this study.

\section{Isolates}

Three chosen Indian field isolates of A paragallinarum were characterized by authors in the course of 2012-2015 [24,25]. The isolates were revived from storage and used for molecular characterization.

\section{DNA isolation}

Brain-heart infusion broth supplemented with $1 \%(\mathrm{~W} / \mathrm{V})$ sodium chloride, $0.0025 \%(\mathrm{~W} / \mathrm{V})$ reduced nicotinamide adenine dinucleotide, and $1 \%$ $(\mathrm{V} / \mathrm{V})$ filter-sterilized chicken serum were inoculated with single colony of each isolate and kept for overnight incubation at $37^{\circ} \mathrm{C}$. The DNA was extracted from overnight grown bacterial cultures using DNeasy Blood and Tissue DNA Kit (Qiagen, Germany).

\section{HPG-2 PCR confirmation}

The retrieved cultures were reconfirmed for A. paragallinarum by performing species-specific PCR (HPG2-PCR). A set of primers F1 (TGAGGGTAGTCTTGCACGCGAAT) and R1 (CAAGGTATCGATCGTCTCTCTACT) were used to amplify species-specific $500 \mathrm{bp}$ fragment of $A$. paragallinarum [9].

\section{Amplification and sequencing of 16S rRNA}

The genomic DNA extracted in the previous steps was used as template DNA. Bacterial 16S region gene was amplified using standard PCR reaction. The primer pair 27F (AGAGTTTGATCMTGGCTCAG) and 1492R (TACGGYTACCTTGTTACGACTT) was used in a PCR reaction with an annealing temperature of $57^{\circ} \mathrm{C}$. After amplification, products were purified using Invitrogen PCR product purification kit (Life Technologies, USA) and were directly sequenced using an ABI PRISM BigDye Terminator V3.1 kit (Applied Biosystems, USA). The sequences were analyzed and edited using Sequencing Analysis V5.2 Software (Applied Biosystems, USA) and compared with already published sequences in the GenBank, NCBI, with the help of BLAST tool [26]. The sequences were also submitted to GenBank, NCBI, to obtain unique accession number.

\section{Multiplex PCR}

The genomic DNA extracted was further used as PCR template for multiplex PCR method. Briefly, the PCR reactions were performed for a total volume of $25 \mu 1$ containing $100 \mathrm{ng}$ of template DNA, $1 \times$ PCR buffer, $0.2 \mathrm{mM}$ of each dNTP, $0.2 \mu \mathrm{M}$ Page serovar-specific primers, and 1.25 units of DNA Taq polymerase. The sequences of primers used for amplification of DNA are as follows:

\begin{tabular}{llc}
\hline Primer & Sequence (5'-3') & $\begin{array}{c}\text { Amplicon } \\
\text { size (kbp) }\end{array}$ \\
\hline ABC & GGCTCACAGCTTTATGCAACGAA & - \\
forward & & \\
A reverse & CGCGGGATTGTTGATITGTT & 0.8 \\
B reverse & GGTGAATTCACCACACCAC & 1.1 \\
C reverse & TAATTTCTTATTCCAGCATCAATACCAT & 1.6 \\
\hline
\end{tabular}

The amplification steps were carried out as per the standard protocol, and PCR products were analyzed using $2 \%(\mathrm{~W} / \mathrm{V})$ agarose gel electrophoresis [15].

\section{Results and Discussion}

\section{HPG-2 PCR confirmation}

HPG2-PCR is a sensitive and reliable method for species-specific identification of A. paragallinarum [27]. All three isolates after HPG2-PCR produced species-specific 500 bp product (Figure-1). This report is similar to the earlier reports $[9,16,27,28]$.

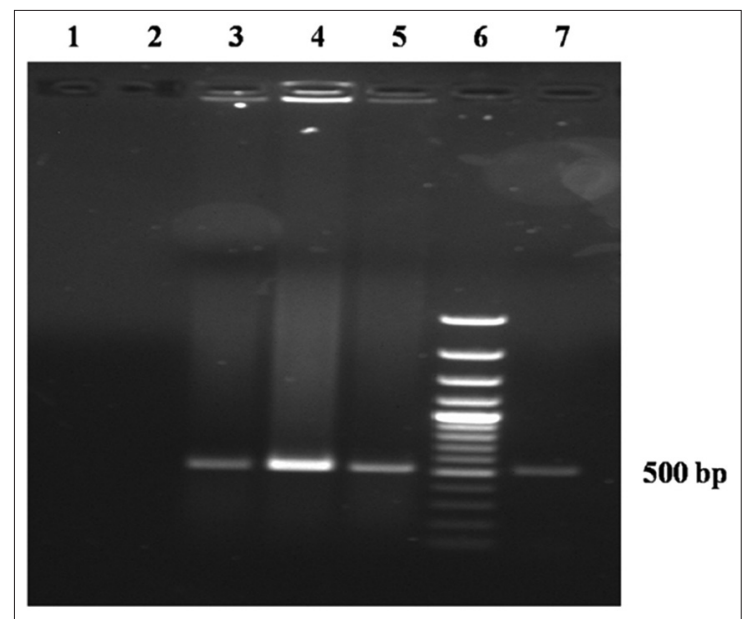

Figure-1: Haemophilus paragallinarum 2 polymerase chain reaction confirmation of Avibacterium paragallinarum (Lane 1 and 2: No template control, Lane 3, 4, and 5: A. paragallinarum isolates, Lane 6: 100 bp plus DNA Ladder, and Lane 7: Reference strain of $A$. paragallinarum). 
Table-1: NCBI accession number assigned to $16 \mathrm{~S}$ rRNA sequences of Indian field isolates of Avibacterium paragallinarum.

\begin{tabular}{lll}
\hline Organism & Strain & $\begin{array}{l}\text { Accession } \\
\text { number (NCBI) }\end{array}$ \\
\hline Avibacterium paragallinarum & IND101 & KX759522 \\
Avibacterium paragallinarum & IND102 & KX722532 \\
Avibacterium paragallinarum & IND103 & KX759523 \\
\hline
\end{tabular}

rRNA=Ribosomal RNA

Table-2: Multiplex PCR assay of Avibacterium paragallinarum.

\begin{tabular}{cc}
\hline Strain & $\begin{array}{c}\text { Amplicon Serovar } \\
\text { size }\end{array}$ \\
\hline
\end{tabular}

Avibacterium paragallinarum IND $101 \quad 0.8 \mathrm{Kbp} \quad \mathrm{A}$ Avibacterium paragallinarum IND $102 \quad 1.1 \mathrm{Kbp} \quad \mathrm{B}$ Avibacterium paragallinarum IND $103 \quad 1.6 \mathrm{Kbp} \quad \mathrm{C}$ $\mathrm{PCR}=$ Polymerase chain reaction

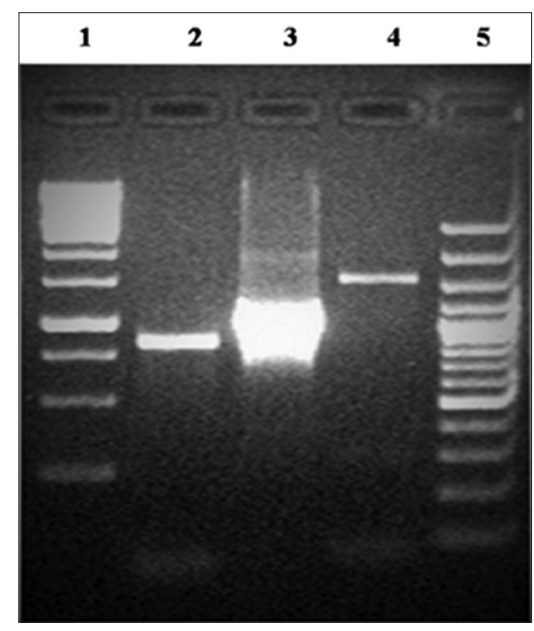

Figure-2: Agarose gel electrophoresis of multiplex polymerase chain reaction products from field isolates of Avibacterium paragallinarum (Lane 1 and 5: Molecular weight markers, Lane 2: Strain IND 101, Lane 3: Strain IND 102, and Lane 4: Strain IND 103).

\section{Amplification and sequencing of 16S rRNA}

The sequences obtained from all three isolates showed 96-99\% homology with the NCBI database reference strains of $A$. paragallinarum. The aligned partial sequences of $16 \mathrm{~S}$ rRNA were submitted to GenBank and accession numbers were obtained (Table-1). These results are in concurrence with the previous findings $[14,26]$.

\section{Multiplex PCR}

In this test, bacterial HMTp210 gene was amplified using standard PCR reaction. The set of four primers including $\mathrm{ABC}$ forward, A reverse, $\mathrm{B}$ reverse, and $\mathrm{C}$ reverse were used.

DNA sample of strain IND101 showed amplicon of size $0.8 \mathrm{Kbp}$ which corresponds to detection of serovar A. Further, strain IND102 and strain IND103 generated amplicons of size $1.1 \mathrm{Kbp}$ and $1.6 \mathrm{Kbp}$, respectively, which matched to serovar $\mathrm{B}$ and serovar $\mathrm{C}$ (Figure-2 and Table-2). These reports of serovar identification of $A$. paragallinarum are in agreement with other reports [29,30].
For preventive measure and a better understanding of a disease, it is essential to identify pathogen on serovar level. Infectious coryza is caused by all three serovars of $A$. paragallinarum, i.e., serovars $\mathrm{A}, \mathrm{B}$, and $\mathrm{C}$. In this study, for the very first time, multiplex PCR for serological classification of Indian $A$. paragallinarum was introduced. Through the use of multiplex PCR, this study notably reconfirms the co-occurrence of $A$. paragallinarum serovar B in India [24]. However, earlier report had expressed only $A$. paragallinarum serovar A and serovar C are prevalent in India [19]. Hence, the present study and application of multidimensional modern tools to identify and confirm $A$. paragallinarum serotypes found effective.

\section{Conclusion}

In this study, three field isolates of $A$. paragallinarum were confirmed for their identity using species-specific PCR (HPG-2 PCR) and 16S rRNA sequencing. The isolates were also characterized on the serological level using multiplex PCR method. Both identification tools are found to be more effective and reliable in identification and differentiation of A. paragallinarum field isolates from other nonpathogenic avian Haemophili and respiratory pathogens. The multiplex PCR analysis of these isolates revealed the co-occurrence of all three serotypes, i.e., A, B, and $\mathrm{C}$ of $A$. paragallinarum in India. Application of the present technique found to be simple and sensitive for serological identification of $A$. paragallinarum. Finally, the application of these next-generation diagnostic tools would be much valuable to formulate quick and correct prevention and control measures against this detrimental poultry pathogen.

\section{Authors' Contributions}

VVP designed and carried out the research work. DM and DVM supervised the research work. VVP drafted the manuscript. DM and DVM revised the manuscript. All authors read and approved the final manuscript.

\section{Acknowledgments}

The authors deeply acknowledge the support and research facilities provided to them by concerned authorities of Biotechnology Research Centre, COCSIT, Latur. This study was funded by authors.

\section{Competing Interests}

The authors declare that they have no competing interests.

\section{References}

1. Blackall, P.J. and Soriano, V.E. (2005) Infectious coryza and related bacterial infections. In: Saif, Y.M., editor. Diseases of Poultry. Iowa State University Press, Ames, Iowa. p789-803.

2. Soriano, V.E. and Terzolo, H.R. (2004) Haemophilus paragallinarum: Etiology of infectious coryza. Vet. Mex., 35(3): 245-259.

3. Nandre, R.M., Eo, S.K., Park, S.Y. and Lee, J.H. (2015) 
Comparison of a live attenuated Salmonella Enteritidis vaccine candidate secreting Escherichia coli heat-labile enterotoxin B subunit with a commercial vaccine for efficacy of protection against internal egg contamination by Salmonella in hens. Can. J. Vet. Res., 79: 235-240.

4. Nandre, R.M., Matsuda, K., Chaudhari, A.A., Kim, B. and Lee, J.H. (2012) A genetically engineered derivative of Salmonella Enteritidis as a novel live vaccine candidate for salmonellosis in chickens. Res. Vet. Sci., 93(2): 596-603.

5. Schalm, O.W. and Beach, J.R. (1936) Studies on infectious coryza of chickens with special reference to its etiology. Poult. Sci., 15: 473-482.

6. Page, L.A. (1962) Haemophilus infections in chickens-1: Characteristics of 12 Haemophilus isolates recovered from diseachickens. Am. J. Vet. Res., 23: 85-95.

7. Anjaneya, A., Singh, S.D., Dhama, K., Wani, M.Y., Gowthaman, V. and Chawak, M.M. (2014) Molecular characterization of Avibacterium paragallinarum isolated from poultry flocks of India. Asian J. Anim. Vet. Adv., 9(7): 440-451.

8. Blackall, P.J. and Matsumoto, M. (2003) Infectious coryza. In: Saif, Y.M., Barnes H.J., Glisson, J.R., Fadly, A.M., McDougald, L.R. and Swayne D.A., editors. Diseases of Poultry. $11^{\text {th }}$ ed. Iowa State University Press, Ames, Iowa. p691-703.

9. Chen, X., Miflin, J.K., Zhang, P. and Blackall, P.J. (1996) Development and application of DNA probes and PCR tests for Haemophilus paragallinarum. Avian Dis., 40: 398-407.

10. Blackall, P.J., Morrow, C.J., Mcinnes, A., Eaves, L.E. and Rogers, D.G. (1990) Epidemiologic studies on infectious coryza outbreaks in northern New South Wales, Australia, using serotyping, biotyping, and chromosomal DNA restriction endonuclease analysis. Avian Dis., 34: 267-276.

11. Miflin, J.K., Chen, X. and Blackall, P.J. (1997) Molecular characterization of isolates of Haemophilus paragallinarum from China by ribotyping. Avian Pathol., 27: 119-127.

12. Soriano, V.E., Tellez, G., Hargis, B.M., Newberry, L., Salgado-Miranda, C. and Vázquez, J.C. (2004) Typing of Haemophilus paragallinarum strains by using enterobacterial repetitive intergenic consensus-based polymerase chain reaction. Avian Pathol., 48: 890-895.

13. Corney, B.G., Diallo, I.S., Wright, L., Hewitson, G., de Jong, A., Tolosa, X., Burrell, P., Duffy, P., Rodwell, B., Boyle, D.B. and Blackall, P.J. (2008) Rapid and sensitive detection of Avibacterium paragallinarum in the presence of other bacteria using a 5 Taq nuclease assay: A new tool for diagnosing infectious coryza. Avian Pathol., 37: 599-604.

14. Christensen, H., Blackall, P.J. and Bisgaard, M. (2009) Phylogenetic relationships of unclassified, satellitic Pasteurellaceae obtained from different species of birds as demonstrated by $16 \mathrm{~S}$ rRNA gene sequence comparison. Res. Microbiol., 160: 315-321.

15. Sakamoto, R., Kino, Y. and Sakaguchi, M. (2012) Development of a multiplex PCR and PCR-RFLP method for serotyping of Avibacterium paragallinarum. J. Vet. Med. Sci., 74(2): 271-273.

16. Thenmozhi, V. and Malmarugan, S. (2013) Isolation, identification and anti-biogram pattern of Avibacterium paragallinarum from Japanese quails. Tamil Nadu J. Vet. Anim. Sci., 9(4): 253-258.

17. Rajurkar, G., Roy, A. and Yadav, M.M. (2010) Antimicrobial sensitivity pattern of Haemophillus paragallinarum isolated from suspected cases of infectious coryza in poultry. Vet. World, 3(4): 177-181.

18. Kaur, J., Sharma, N.S., Gupta, K. and Singh, A. (2004) Epidemiological studies on infectious coryza in chickens in Northern India. Indian J. Anim. Sci., 74(2): 462-465.

19. Tongaonkar, S., Deshmukh, S. and Blackall, P.J. (2002) Characterization of Indian isolates of Haemophilus paragallinarum. In: Proceedings of the $51^{\text {st }}$ Western Poultry Disease Conference, Peurto Vallajarta, Mexico. p58.

20. Rajurkar, G., Roy, A. and Yadav, M.M. (2009) An overview on epidemiologic investigations of infectious coryza. Vet. World, 2(10): 401-403.

21. Nandre, R.M., Jawale, C.V. and Lee, J.H. (2013) Adjuvant effect of Escherichia coli heat labile enterotoxin B subunit against internal egg contamination in domestic fowl immunised with a live Salmonella enterica serovar Enteritidis vaccine. Vet. J., 197(3): 861-867.

22. Nandre, R.M. and Lee, J.H. (2014) Generation of a safe Salmonella gallinarum vaccine candidate that secretes an adjuvant protein with immunogenicity and protective efficacy against fowl typhoid. Avian Pathol., 43(2): 164-171.

23. Nandre, R.M., Matsuda, K. and Lee, J.H. (2013) Efficacy for a new live attenuated Salmonella Enteritidis vaccine candidate to reduce internal egg contamination. Zoonoses Public Health, 61(1): 55-63.

24. Patil, V.V., Mishra, D.N. and Mane, D.V. (2016) Isolation, characterization and serological study of Avibacterium paragallinarum field isolates from Indian poultry. J. Anim. Poult. Sci., 5(1): 13-20.

25. Patil, V.V., Mishra, D.N. and Mane, D.V. (2017) Virulence pattern of Avibacterium paragallinarum isolates studied from Indian field condition. Int. J. Livest. Res., 7(2): 201-207.

26. Chukiatsiri, K. (2011) Faculty of Veterinary Science. Virulence Factors of Avibacterium paragallinarum Isolated from Chickens in Thailand (Doctoral Thesis). Chulalongkorn University, Bangkok, Thailand.

27. Muhammad, T.M.N. and Sreedevi, B. (2015) Detection of Avibacterium paragallinarum by polymerase chain reaction from outbreaks of infectious coryza of poultry in Andhra Pradesh. Vet. World, 8(1): 103-108.

28. Byarugaba, D.K., Minga, U.M., Gwakisa, P.S., KatungukaRwakishaya, E. and Bisgaard, M. (2007) Virulence characterization of Avibacterium paragallinarum isolates from Uganda. Avian Pathol., 36(1): 35-42.

29. Fedawy, HS., Salama, S.S., Ali, A., Rabie, N.S. and El-Kady M.F. (2016) Phenotypic and genotypic characterization of Avibacterium paragallinarum isolated from layer chicken flocks in Egypt yearling 2013-2015. Am. J. Res. Commun., 4(12): 23-34.

30. Nouri, A., Banani, M., Goudrzi, H., Pourbakhsh, S.A. and Mirzaeil, S.G. (2014) Retrospective detection of Avibacterium paragallinarum serovar B in egg yolk materials by PCR. Arch. Razi. Inst., 69(2): 179-183. 